\title{
Helsegevinst ved sykling til jobb
}

Fysisk aktivitet har forebyggende effekt på mange forskjellige sykdommer, som for eksempel hjerte- og karsykdommer, diabetes, tykktarms- og brystkreft (1). Likevel har det vist seg vanskelig å få befolkningen til å endre vaner til en mer fysisk aktiv livsstil. Flere voksne og middelaldrende driver fysisk aktivitet og sport i fritiden, men dette gjelder en begrenset del av befolkningen, og primært de med høyere sosioøkonomisk status. En viktig måte å sikre tilstrekkelig høyt fysisk aktivitetsnivå på er å inkludere aktivitet som en del av hverdagslivet. Fysisk aktiv transport, som det å gå eller sykle til jobben, er aktivitetsformer mange mennesker har mulighet til å gjennomføre.

I dette nummer av Tidsskriftet har Tjelta og medarbeidere undersøkt helseeffekter av å sykle til jobben gjennom et helt år hos 25 menn og kvinner (2). De finner markante forbedringer i oksygenopptak, HDL-kolesterol og kroppsmasseindeks (BMI).

I den første perioden av studien, da vær og føre var egnet til sykling, var forbedring i oksygenopptak på $22 \%$, noe som tilsvarer det man finner i kontrollerte treningsforsøk. Intensiteten ved å sykle til jobben er mindre enn ved normal trening, men forklaringen kan være at denne type aktivitet skjer to ganger daglig. Studien er dessverre uten kontrollgruppe, men en forbedring på $22 \%$ i oksygenopptak er ikke noe som skjer av seg selv. Det kan derfor etter all sannsynlighet tilskrives intervensjonen. I studier har man funnet en reduksjon i dødelighet på $44 \%$ ved tilsvarende endring i oksygenopptaket (3). Bekreftelse på at sykling alene reduserer dødeligheten finnes også i andre studier. Andersen og medarbeidere undersøkte den isolerte betydningen av det å sykle til jobben (4). Etter å ha justert for kolesterol, overvekt, blodtrykk, utdanningslengde og annen fysisk aktivitet fant de at dødeligheten blant dem som syklet til jobben var $28 \%$ lavere enn blant dem som brukte passiv transport.

I tillegg til en forbedring av oksygenopptaket, fant Tjelta og medarbeidere også en $15 \%$ økning i HDL-kolesterol. Økningen man kan forvente i HDL-kolesterol gjennom statinbehandling er i størrelsesordenen 5-15\% (5), mens annen medikamentell behandling gir en økning på $15-35 \%$. Siden sykling har positive effekter på flere sykdommer, mens medikamentell behandling er spesifikk og har bivirkninger, vil vi tro at helseeffekten er større ved sykling enn ved medikamentell behandling.

Tjelta og medarbeidere er beskjedne når de beskriver endringene i kroppsmasseindeks som små og nærmest ubetydelige. Fra deres tabell 2 ser vi tydelig at det har vært en signifikant nedgang i BMI for deltakerne generelt, og for menn spesielt. I løpet av det første halve året, da det ble syklet mest, ble mennenes BMI redusert fra 28,0 til 27,0, en reduksjon som tilsvarer 3,2 kg for menn som er $180 \mathrm{~cm}$ høye. Til sammenlikning økte BMI blant norske 40-42 åringer fra slutten av 1960-årene til slutten av 1990-årene fra 24,9 til 26,5, noe som tilsvarer en vektøkning på 5,2 kg for menn som er $180 \mathrm{~cm}$ høye. Dette er tall som ofte blir brukt for å beskrive nordmenns økende vekt, og sammenliknet med dette må en reduksjon på $3,2 \mathrm{~kg} / \mathrm{mann}$ i løpet av et halvt år med sykling til jobben sies å være en helsemessig betydningsfull vektnedgang.

Det er ingen tvil om at økt fysisk aktivitet i befolkningen vil være bra for folkehelsen i Norge. Flere epidemiologiske studier frem- hever positiv effekt av fysisk aktivitet på livsstilssykdommer og dødelighet. I slike epidemiologiske studier kan man imidlertid ikke vurdere muligheten for å få befolkningen til å endre vaner, og det er derfor vanskelig å tolke hvor stort folkehelsepotensialet er. Det er en stor mangel på intervensjonsstudier som viser at det er mulig å få folk til å endre atferd. Slik sett er studien til Tjelta og medarbeidere viktig fordi den viser at det faktisk er mulig å få inaktive til å sykle til jobben. De inaktive er helsemessig den viktigste gruppen å nå, men normalt en vanskelig gruppe å motivere til økt fysisk aktivitet.

Siden tiltak for å få folk til å sykle til jobb som regel ikke evalueres, er det vanskelig å si noe bestemt om hvilke virkemidler som må til for å få flere nordmenn til å sykle til jobben. Holder det med å oppfordre arbeidsgivere til å legge til rette for sykling, med f.eks. god sykkelparkering og gode fasiliteter for dusjing og skifting, eller må myndighetene ta et krafttak for bygging av sykkelstier som kan brukes sommer som vinter? Ett mulig tiltak er at arbeidsgivere sponser ny sykkel på sine ansatte dersom de bandt seg til å sykle $i$ en avtalt periode. Et annet attraktivt tiltak kunne være å få kortere arbeidstid for å sykle til jobben. Mange har i dag tilsvarende mulighet for å trene i arbeidstiden. Vi tror det må betydelige tiltak til for å få inaktive nordmenn til å sykle til jobben. Uavhengig av mulige tiltak fra arbeidsgiver må myndighetene kraftig forbedre nettet av sykkelstier i Norge. I forhold til Nederland og Danmark er sykkelstier lite prioritert. Enkelte steder er det gjort mye, men det er stadig lang vei å gå før de store byer i Norge har akseptable forhold for sykling.

\section{Lars Bo Andersen}

lboandersen@health.sdu.dk

Elling Bere

elling.bere@uia.no

Lars Bo Andersen (f. 1950) er professer ved ldrettsmedisinsk seksjon ved Norges idrettshøgskole og forsker ved Institut for Idræt og Biomekanik ved Syddansk Universitet i Odense.

Elling Bere (f. 1974) er førsteamanuensis ved Institutt for folkehelse, idrett og ernæring ved Universitetet $i$ Agder.

Oppgitte interessekonflikter: Ingen

\section{Litteratur}

1. Haskell WL, Lee IM, Pate RR et al. Physical activity and public health: updated recommendation for adults from the American College of Sports Medicine and the American Heart Association. Circulation 2007; 116: 1081-93.

2. Tjelta LI, Kvåle OH, Dyrstad SM. Helseeffekter av sykling til og fra jobb. Tidsskr Nor Legeforen 2010; 130: 1246-9.

3. Blair SN, Kohl HW, Barlow CE et al. Changes in physical fitness and all-cause mortality. JAMA 1995; 273: 1093-8.

4. Andersen LB, Schnohr P, Schroll M et al. All-cause mortality associated with physical activity during leisure time, work, sports, and cycling to work. Arch Intern Med 2000; 160: 1621-8.

5. Natarajan P, Ray KK, Cannon CP. High-density lipoprotein and coronary heart disease: current and future therapies. J Am Coll Cardiol 2010; 55: 1283-99. 